\title{
DOES HUME HAVE A THEORY OF JUSTICE?
}

\author{
David A. Reidy, Jr. \\ University of Kansas
}

\section{INTRODUCTION}

For Hume, "virtuous actions derive their merit only from virtuous motives, and are consider'd merely as signs of those motives" (Treatise, 478). Hume distinguishes virtuous from vicious motives by the pleasure and pain each respectively produces upon its "mere view and contemplation." We call a charitable act virtuous, Hume contends, because when we contemplate charity as a motivation to act we naturally feel a certain pleasure. The origin of this pleasure is obvious in cases where we benefit directly from the contemplated charitable act. It is less so, however, in cases where we do not. Historical acts of charity in distant lands do not benefit present individuals. Yet, we praise such remote acts of charity. Hume argues that sympathy, or "fellow-feeling," communicates to us the pleasure such acts produce; because sympathy "connects" all humans, we "feel" the pleasures and pains of others. We approve or disapprove of actions accordingly.1 Because humans naturally perform some actions out of charity and because humans naturally approve of such actions, charity is, for Hume, a natural virtue.

Hume begins Part II, Book III of the Treatise with a problem. Given the foregoing, whence arises the virtues associated with justice? Hume finds no one common naturally occurring motivation to act justly. Unable to explain the virtues associated with justice in terms of naturally occuring motivations to act, of which humans naturally approve, Hume concludes that "we must allow, that the sense of justice and injustice is not deriv'd from nature, but arises artificially, tho' necessarily from education, and human conventions" (Treatise, 483).

Justice is, for Hume, an artificial virtue in two respects. First, human nature alone does not motivate humans to act justly; human nature, given certain conventions, motivates humans to act justly. Second, the contemplation of a just act in and of itself does not naturally produce pleasure; the contemplation of a just act given a certain conventional context produces pleasure. Only within a context of certain artificial

1 Actually, "corrected sympathy" explains our approval of remote acts of justice. The more remote a just act, the fainter the impression of pleasure sympathy communicates to us when we contemplate that act. Yet, we approve of remote acts of justice just as heartily as proximate acts of justice. Hume argues that in these cases we "correct" or "modify" our judgment to take account of sympathy's inability to communicate lively impressions over great distance or time. 
human conventions does human nature lead humans to act justly and to approve of just acts.

This alone, of course, does not adequately explain the virtues associated with justice. Hume must explain the artificial human conventions that lead humans to act justly and approve of just acts. This paper will focus upon Hume's account of what motivates humans to develop the conventions of justice and his account of the content of those conventions. But first, a brief sketch of Hume's story regarding the conventions of justice is in order.

\section{JUSTICE AND CONVENTION: HUME'S STORY BRIEFLY TOLD}

Individuals do not fare as well outside society as within it. Society provides individuals with security, stability and material goods otherwise unavailable; family life teaches this. Thus, Hume argues, human nature, specifically, self-love, naturally produces in each individual the desire to live in society.

Self-love, however, pulls also in an opposite direction. Individuals desire society, in part, because society increases the available supply of transferable goods, and everyone wants to increase their share of transferable goods. Because individuals desire an increase in their share of transferable goods, given relative scarcity, they will, when able, simply take from the socially produced supply of transferable goods that which they desire. Self-love, unconstrained, leads individuals to render social relations insecure, unstable and unproductive. The contrary movements of self-love, Hume argues, prevent individuals from realizing that which they most desire. 2

Of course, humans do achieve society. "[N]ature," Hume argues, "provides a remedy in the judgment and understanding, for what is incommodious in the affections" (Treatise, 489). When humans realize that conflict over the possession of transferable goods stands as the principal obstacle to social relations, they:

"...seek...a remedy, by putting those goods, as far as possible, on the same footing with Inon-transferable

2 One might categorize various theories of justice according to that aspect of economic life most central to the theory. For example, while Humean, Marxist and liberal theories of justice all take account of the various moments in economic life, each identifies a different moment as central to its theory of justice. Hume builds his theory of justice as a solution to certain problems regarding the consumption of transferable goods. Marx builds his theory of justice as a solution to problems regarding the production of goods. And liberals build their theory of justice as a solution to problems regarding the distribution of goods. 
goods]. This can be done after no other manner, than by a convention enter'd into by all the members of the society to bestow stability on the possession of those external goods, and leave every one in the peaceable enjoyment of what he may acquire by his fortune and industry. By this means, every one knows what he may safely possess; and the passions are restrain'd in their partial and contradictory motions" (Treatise, 489).

Simply put, judgment and understanding lead humans to see that they best realize their selfish desires through human conventions regarding property, right and obligation. And so, humans, acting out of enlightened self-interest, produce and maintain conventions regarding the possession and transfer of property and the performance of promises. Hume calls these conventions the "rules of justice."

Hume does not suggest that these conventional rules of justice arise out of a social contract. On Hume's view, they could not, for the very obligations which constitute a contract arise out of the conventional rules of justice. The rules of justice arise rather as the result of self-interest operating in association with intelligent reflection upon experience over time. Hume suggests that the conventional rules of justice emerge in a manner analogous to that by which two individuals, each wanting to cross a river but unable to promise anything to the other, perhaps even unable to speak to the other, come to row together a single boat across the river. Every individual desires to improve her security, stability and material well-being. Over time, Hume argues, every individual learns that she satisfies her individual desires best if she individually conforms her conduct to conventional rules governing social relations, provided others do the same. Individuals produce and sustain the practice of justice out of selfinterest.

Although individuals produce and initially practice justice solely out of self-interest, they come in time to practice justice also because it is morally right to do so. Hume argues that the moral approbation of justice, the status of justice as a virtue, arises not out of self-interest, but out of each individual's sympathy with the public interest. Individuals need not practice justice for long before they will realize that justice works to everyone's individual advantage; it furthers the public or general interest. Thus, the mere contemplation of a just act produces, through the operation of sympathy, a pleasure, which the understanding then corrects (to account for the failure of sympathy to communicate pleasure without a loss in vivacity across vast distances of time and space). ${ }^{3}$ In this way, justice acquires the status of a (artificial) moral virtue.

3 In his effort to explain the uniformity and universality of moral evaluation, Hume also argues that the nature of language and necessities of 
Now, while the foregoing sketch does not represent completely Hume's views on justice, it does, I hope, represent those views with detail sufficient to support a more careful investigation into a few chapters in Hume's story. It is to that investigation I now turn.

\section{SELF-INTEREST AND JUSTICE}

Hume states "that 'tis only from the selfishness and confin'd generousity of men, along with the scanty provision nature has made for his wants, that justice derives its origin" (Treatise, 495). Hume grounds justice in self-interest and the fact that, at best, our natural generosity extends about as far as the immediate family (and sometimes not even that far). 4 In short, for Hume, the conventional rules of justice sprout from the soil of self-interest. Moreover, prudent self-interest alone, Hume argues, will sustain the practice of justice (at least in a society with very few resources).

Now, Hume does not explicitly say what he means by self-interest or self-love. He appears to have in mind that force in human nature which drives individuals to satisfy their desires, or to place their interests ahead of the interests of others. Prima facie, Hume appears in the sections on the origin of justice in the Treatise to be an egoist, a hedonist, or both. But Hume acknowledges elsewhere that humans sometimes act for nonhedonistic and non-egoistic reasons (See, e.g., Enquiry Concerning the Principles of Morals, hereinafter EPM, Appendix II; Treatise, p. 439.) For example, humans eat food, at least in the first instance and sometimes quite often, not because eating food produces pleasure, but because human nature provides humans with a desire to eat food. And, humans seek revenge not out of a desire to secure a self-centered good, but to visit pain upon another. While humans naturally desire pleasure and the absence of pain, not all desires are hedonistic. And while humans naturally wish to satisfy their desires, not all desires are self-directed.

But what, then, does Hume mean when he claims that the origin of justice is self-interest? He might mean that justice enables everyone to satisfy overall more of their egoistic or egoistic-hedonistic desires, regardless of the content of those desires. Or, perhaps Hume means that

communication force individuals to take a more general point of view when they speak of matters moral. Thus language, sympathy and judgment together provide moral evaluations with their characteristic uniformity and universality.

4 Also, resources must be relatively scarce for justice to arise. Hume argues that were nature to bestow an abundance of resources so that everyone had all that she desired, justice would serve no purpose and would not arise. Some have interpreted Marx to have held a similar view, that the abundance available within a communist state (and the elimination of class conflict) renders justice unnecessary. 
justice enables everyone to satisfy best their instinctive desires for security, stability and material goods. Hume's meaning is just not clear.

Hume often speaks of self-interest and (limited) benevolence as the two fundamental forces at work in human nature. And he often speaks as if only pleasure and pain activated these forces. But this leaves certain instinctive desires, for example, the desires for food, sex and revenge, unexplained in terms of human nature. Hume recognized this and allowed that some desires arise out of neither self-interest nor benevolence, but some other force in human nature. This is correct. But the possibility that human nature includes primitive motivational forces other than selfinterest and benevolence complicates Hume's account of justice in a way Hume does not adequately address.

Hume argues that all humans desire security, stability and material goods. He does not say whether humans desire these for the pleasure they produce or out of instinct, as with the desire for food, sex or revenge. Hume does tie these desires to self-interest, but he does not say whether he means just that the satisfaction of these desires furthers self-interest (which might be true of the satisfaction of any desire, provided it is my desire) or whether the desires arise out of self-interest (which would be true for only egoistic desires). In any case, Hume suggests that humans seek and value social relations because only within social relations do humans satisfy their desires for security, stability, and material goods; humans desire society as a means to certain desired ends. Humans do not, Hume implies, desire social relations for their own sake.

But Hume's discussion of self-interest and human motivation does not rule out the possibility that human nature might provide humans with a direct desire for social relations, a desire similar to the desire for food. Indeed, Hume comes close to suggesting just such a desire. Speaking of the usefulness of the social virtues, Hume states "that the end, which they have a tendency to promote, must be some way agreeable to us, and take hold of some natural affection" (EPM, p. 214). Hume then states, however, that this end, the preservation of society, must please either "from considerations of self-interest, or from more generous motives and regards" (Id., p. 215). Because benevolence cannot account for the scope of justice, Hume continues, justice must, by default, arise out of self-interest. 5

5 Hume, of course, acknowledges that humans will naturally act out of benevolence, but only with respect to immediate family and the like. Humans do not act out of benevolence toward strangers or the public in general. Thus, benevolence, Hume argues, could not give rise to justice, a virtue whose scope exceeds immediate family.

Given that benevolence for Hume entails something like putting the interests of another before one's own interests, Hume is correct that benevolence generally does not reach much past immediate family and 
Hume's argument here turns on the impossibility of justice arising out of some third force in human nature, some natural instinct like the desire to eat. Hume considers this possibility in the EPM but quickly dismisses it. He argues that if justice arises out of some instinctive primitive force at work in human nature, then property rights must arise out of the same instinctive primitive force, for property rights are the object of justice. But nothing, Hume suggests, could be more absurd than this (Id., p. 201).

This argument fails to rule out the possibility that justice might arise out of a primitive force at work in human nature other than self-interest or benevolence. Hume considers and rejects only the possibility that justice arises directly out of a natural instinct or desire for justice. He does not consider that justice might arise indirectly out of a force in human nature other than self-interest, benevolence or a desire for justice itself. Specifically, Hume does not consider whether human nature provides individuals with a raw desire for social relations. Interestingly, Hume does argue that humanity's "first state and situation may justly be esteem'd social" (Treatise, p. 493). But he does not consider explaining that state as the result of a force in human nature both weaker, but with greater scope, than benevolence and distinguishable from self-interest, something like an instinct to recognize the interests of others as a part of one's own interests, an instinct for the collective.

I am not arguing here that human nature includes such an instinct, although I would not be surprised if it did. I am arguing only that Hume's argument that justice arises out of self-interest is incomplete without his addressing this possibility. If human nature included such a raw desire for social relations, Hume, of course, could still argue that individuals could not satisfy this natural desire except through the operation of conventions. After all, human nature presumably provides each individual with a desire to communicate with others, to use language, yet this desire cannot be satisfied except through the operation of conventions. Justice might arise out of a natural force other than self-interest or benevolence and yet still remain artificial or conventional in the same way language is. Indeed, in several passages Hume speaks as if he has this in mind, despite his repeated and ambiguous references to self-interest. 6

loved ones; justice could not originate in benevolence. The issue I am raising is whether self-interest is the only alternative origin.

6 Because Hume locates the origin of the practice of justice in "selfinterest," and the origin of the moral approbation of justice in "the public interest," he has been interpreted often as either a proto-rational-choicetheorist (in the spirit of Gauthier) or as a proto-utilitarian. The ambiguity of Hume's presentation has encouraged these readings.

Hume does not present a proto-utilitarian theory of justice. Hume offers a descriptive, naturalistic theory of justice, not a normative theory. But more importantly, Hume does not explain justice as the maximization 


\section{CONVENTIONS AND POWER}

Hume suggests that the conventions constituting the rules of justice might have emerged in a manner similar to that by which two individuals desiring to cross a river in a single boat come to row together. The analogy is a poor one. Hume assumes that the two individuals share a similar aim, getting across the river. Moreover, he assumes that the two individuals agree to ride in a single boat. And further, he assumes that neither desires a free-ride, each is willing to row even if the other is rowing already. All that the two individuals in Hume's rowing example must do is coordinate their rowing. That humans routinely solve such coordination problems through convention cannot be doubted. But the problems Hume identifies as the principal obstacles to society are not mere coordination problems. They are conflict problems.

Hume's rowing example would be more effective, given the point he wishes to make with it, were he to begin with two individuals, who each prefer to take the one available boat across the river alone, rather than together, but who also each prefer to cross the river rather than not cross the river. Such a scenario reflects more accurately the conflicts that arise inevitably over the possession and use of transferable goods as social relations emerge. On these facts, and given each individual's desire to travel alone, it is less than obvious that the reciprocal give and take Hume imagines characteristic of convention-building would produce an optimal (or any) convention, i.e., one through which both individuals cross the river. The stronger of the two individuals will likely cross the river alone.

Hume needs additional facts to make his point about the origin of conventions. Suppose that person A was not capable of excluding person B from the boat without great expense and risk, and conversely, that person $B$ was not capable of excluding person $A$ from the boat without similar expense and risk. Given this fact, persons A and B will in time undoubtedly seek to avoid their endless confrontation. Assuming, however, that they understand that they share the same aim in part, namely to cross the river, the conventional property right the two will likely settle on will be joint

of social utility, understood (setting aside the content of preferences) as an aggregate measure of either the strength of individual preferences or the pleasure derived from the satisfaction of individual preferences. Hume comes closer, however, to explaining justice as a conventional social arrangement bargained for by individual rational utility maximizers. But Hume is no proto-Gauthier. Hume argues that the morality of justice, the moral force attendant to the obligations of justice, arises from both selfinterest and sympathy with the public interest. Gauthier rests both the practice and morality of justice on self-interest alone. 
ownership; they will share the boat. Of course, once they settle on sharing the boat, they will, as Hume notes, quickly learn to row together.

Two points should be made here. First, to explain why two individuals with conflicting desires over the use of resources will settle their conflict through conventional property rights rather than force, one must assume both that each individual possesses power sufficient to frustrate the desires of the other and that each individual prefers peace and a partial satisfaction of her preferences to conflict. Hume explicitly states that individuals prefer peace to conflict (the truth of which is not self-evident). Hume is less explicit with respect to the equality of power between individuals. He undoubtedly assumes that with respect to transferable goods individuals, in fact, possess power sufficient to frustrate the desires of others, because everyone must sleep sometime and transferable goods are by definition easily transfered. But this is probably insufficient. Absent a more substantial equality of power between individuals, one Hume does not argue for, it seems likely that some individuals through natural or acquired abilities will find themselves practically invulnerable to the will of others. Hume provides such individuals with no reason to participate in convention-building. ${ }^{7}$

Moreover, because Hume's argument for convention-building rests upon an equal distribution of power among the individual parties to the convention, Hume provides no reason for those with power to include those without power in the convention-building process or treat them as parties to the conventions eventually produced. Hume states:

"Were there a species of creatures intermingled with
men, which, though rational, were possessed of such
inferior strength, both of body and mind, that they were
incapable of all resistance, and could never, upon the
highest provocation, make us feel the effects of their
resentment; the necessary consequence, I think, is that we
should be bound by the laws of humanity to give gentle
usage to these creatures, but should not, properly
speaking, lie under any restraint of justice with regard to
them, nor could they possess any right or property,
exclusive of such arbitrary lords. Our intercourse with
them could not be called society, which supposes a degree

7 Hume cannot invoke the threat of legal sanction as a reason for such powerful individuals to participate in convention-building, for he has not yet argued for executive government. Arguably, where power is unequally distributed among individuals such that some individuals do not need to participate in convention-building to satisfy their preferences, some form of executive government is a necessary condition for the emergence of conventional rules of justice in the first place. 
of equality; but absolute command on the one side, and servile obedience on the other" (EPM, p. 190-191).

The realm of justice simply does not extend, for Hume, to women, the handicapped, children and others unable to pose a threat sufficient to include them in the convention-building process. ${ }^{8}$ To be sure, Hume does not argue that such individuals be mistreated. But he does force them to articulate their claims upon us in the language of pity rather than justice.

Second, the conventional property right most likely to be produced under conditions of relative scarcity and equality of power would be the right to communal possession and use. Hume, however, argues exactly the opposite. He argues that under such circumstances the conventional property right individuals will produce would be the right to ownership of present possessions. Hume does not adequately explain why individuals with equal power will allocate relatively scarce resources in a manner that provides for individual ownership of present possessions. If boats with which to cross a river are relatively scarce and individuals each possess power sufficient to frustrate their exclusion from such resources, any convention grounded in self-interest will involve the mutual possession and enjoyment of the resources in question. But Hume thinks otherwise.

Hume commits an error here. He distinguishes between a convention establishing the stability of possession and a convention allocating possessions (Treatise, 502-503). The former Hume grounds in self-interest. The latter he grounds in custom. Hume, then, does not exactly claim that self-interest leads individuals to the conventional property right to ownership of present possessions. Rather, he claims that self-interest leads individuals to a convention regarding the stability of possession. The force of custom on the imagination then leads individuals to the ownership of present possessions, that being the most natural distribution, given the already-existing convention establishing stability of possession.

But there is no difference between these two conventions. Any convention that establishes the stability of possession also allocates possessions. If self-interest controls the former, it must also control the latter. Of course, if self-interest controls the latter, Hume cannot, as I have argued above, explain through convention the ownership of present possessions. Individuals with equal power will produce, with respect to relatively scarce resources, conventional property rights of a communal variety. To show, with respect to relatively scarce resources, that selfinterest leads individuals to the conventional property right of individual

8 In Book III, Part II, Section XII of the Treatise, Hume argues for the conventional nature of the "female virtues" of chastity and modesty. His argument, however, consistent with the foregoing remarks, supposes that men alone produce the convention that determines these virtues for women. 
ownership of present possessions, Hume must create a distinction where none exists. 9

One final objection to Hume's discussion of the conventional rules of justice. Because Hume sees the rowing of a boat and the use of language as the paradigmatic cases of convention, he assimilates his analysis of the conventional rules of justice to these cases. But the two types of cases could not be more dissimilar.

With respect to rowing a boat, using a language or driving upon the roads, each individual participating in the activity benefits from following the socially prescribed convention, provided others do the same. Moreover, with respect to these activities, the content of the socially prescribed convention will not significantly benefit any one individual or group. Whether the convention a society produces regarding driving prescribes driving upon the left or right side of the road is not important; what is important is that the society produce a convention and stick with it. In such cases, the utility or usefulness of the convention to both individuals and the public at large follows from the existence of the convention, not its content.

Hume analyzes justice in just this way. The usefulness or utility associated with the rules of justice in any society stems not from the specific content of those rules, but from their existence alone. To be sure, Hume argues for particular rules regarding the transfer of property and the performance of promises, but the rules for which he argues are general. With respect to property rights, the particular rules for which Hume argues are even vaguer. In the end, Hume maintains, the play of the imagination rather than considerations of reason or justice will primarily

9 Hume, perhaps, exacerbates this error by applying his analysis not only to the possession of transferable goods but to the possession of land as well. Hume begins the convention-building process with conflicts over transferable goods only. He ends the convention-building process with the absolute property right to individual ownership of both personal and real property presently possessed. At first glance, this suggests philosophical sleight of hand.

Perhaps Hume thought that absolute, individual property rights in land did not need explaining. He may have thought that because land was abundant, any individual excluded from a parcel could always acquire her own parcel down the path. Thus, Hume might argue, conflicts over real property would not cause individuals to undertake the convention-building process. However, once individuals had established conventional property rights regarding personal property, the imagination would naturally lead them to extend those rights to real property as well. This, at least, would limit the weakness of Hume's accout to the origin of absolute property rights in presently possessed transferable property. 
determine the particular content of the rules of justice in any society and their particular application in any case.

Nonetheless, Hume does argue that the particular rules of justice in any society will further the public good. He states:

"If we examine the particular laws, by which justice is directed, and property determined; we shall still be presented with the same conclusion. The good of mankind is the only object of all these laws and regulations. Not only it is (sic) requisite, for the peace and interest of society, that men's possessions should be separated; but the rules, which we follow, in making the separation, are such as can best be contrived to serve farther the interests of society"10 (EPM, p. 192).

Hume fails here to think carefully about justice. From the fact that everyone does better with a system of conventional property rights than without it does not follow that every particular system of conventional property rights is best for everyone, even best for most. The conventions governing property are not like the conventions governing driving. Particular conventional arrangements regarding property rights often significantly benefit particular individuals or groups without benefiting others. Hume offers no argument that those less advantaged by particular conventional arrangements would be worse off under all other conventional arrangements. He argues only that they would be worse off without any conventional arrangement. Hume must argue, if he can, that the particular conventional arrangements regarding property rights he has in mind not only benefit everyone, but benefit everyone more than any other particular conventional arrangement."11

\section{CONCLUSION}

Hume argues effectively against the rationalist tradition in ethics and the natural law/natural rights tradition in jurisprudence. Hume argues less effectively, however, for the conventional nature of justice. Hume fails to ground justice in self-interest, in part because he fails to state explicitly what he means by self-interest, and in part because he fails to consider

10 Of course, Hume means by "society" only those men with sufficient vigor to pose a threat to others, for they are the convention-builders.

11 This requires that Hume unpack the notion of "public good" or "interest of society." It is not clear whether by such phrases Hume means an aggregate calculation of utility, an intuitive estimation of social well-being, or some other notion. Moreover, it is not clear whether he means to include women, children and others not technically within the scope of "society." 
plausible alternative foundations for justice. Further, Hume fails to explain traditional property rights as the result of (everyone's) selfinterest operating indirectly through convention. In the end, while Hume eliminates the possibility that justice can be explained through God or reason, he does not eliminate the possibility that it can be explained through the power of a few, rather than the self-interest of all, operating indirectly through convention.

\section{Works Cited}

David Hume. Enquiries Concerning Human Understanding and Concerning the Principles of Morals. Edited by L. A. Selby-Bigge, revised by P. H. Nidditch. Oxford: Oxford University Press, 1975.

David Hume. A Treatise of Human Nature. Edited by L. A. Selby-Bigge, revised by P. H. Nidditch. Oxford: Oxford University Press, 1978. 